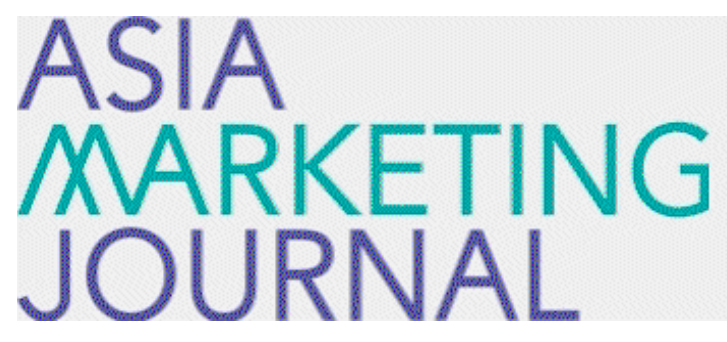

ASIA MARKETING JOURNAL

Volume 1 | Issue 2

Article 8

3-1-1999

\title{
Effects of Design Factors and Shopping Types on Consumer Mood and Store Image
}

Dong Chul Han

Sang Lin Han

Follow this and additional works at: https://amj.kma.re.kr/journal

Part of the Marketing Commons

\section{Recommended Citation}

Han, Dong Chul and Han, Sang Lin (1999) "Effects of Design Factors and Shopping Types on Consumer Mood and Store Image," Asia Marketing Journal: Vol. 1 : Iss. 2 , Article 8.

Available at: https://doi.org/10.53728/2765-6500.1014

This Article is brought to you for free and open access by Asia Marketing Journal. It has been accepted for inclusion in Asia Marketing Journal by an authorized editor of Asia Marketing Journal. 


\title{
Effects of Design Factors and Shopping Types on Consumer Mood and Store Image
}

\author{
Dongchul Han \\ (Seoul Women's University) \\ Sang-Lin Han \\ (Chungnam University)
}

In retailing, it is very important to examine how consumers perceive and react to in-store design factors such as in-store space for walking, product arrangement styles, display types, and window sizes. Furthermore, consumers' perceptions to the various designs would be differentiated by consumers' shopping patterns such as actual shopping versus window shopping. This article investigates how various designs create different consumer reactions measured by consumer mood and store image depending on the types of consumer shopping (i.e. actual shopping vs. window shopping). It was found that design factors such as open, focused, and big created better consumer mood and consumer perception of store image than closed, unfocused, and small. Another finding is that consumer perceptions interact with consumer shopping patterns. Based on the research findings, managerial implications are also discussed 
INTRODUCTION

Everyday, many consumers go to various stores such as department stores, discount stores, and other stores and they naturally meet with various in-store designs. Some studies have been done about design factors in the context of retailing. Markin, Lillis, and Narayana (1976) described the importance of store space in retailing, Donovan and Rossiter (1982) empirically researched store atmosphere from an environmental psychology perspective, and Bellizzi, Crowley, and Hasty (1983) conducted an experimental study about color in store design. Baker, Levy, and Grewal (1992) extended the Donovan and Rossiter(1982)'s store atmosphere study in relation to store image, and Baker, Grewal, and Parasuraman (1994) related store environments to consumer's inference of merchandise quality and store image.

Even though the articles listed above made some contributions to the study of store environmental effects on consumers, this is not quite enough. Two general comments could be made concerning the current research stream. One is that the environmental psychology perspective has been widely immersed into retailing, becoming the major research stream in this kind of research. The other is that those studies have focused on somewhat broad relationships between store environments and consumer reactions. More specific and focused studies have not sufficiently been done yet and this points out the necessity for more research.

\section{CONCEPTUAL BACKGROUND}

Since the mid-sixties, environmental psychology has been largely expanded to the study of marketing area. Nevertheless, one area to which has little been applied is retailing. In other words, even though much research has been done on the applications of environmental factors to various settings, little is done in relation to retail stores. For example, a recent environmental psychology book (Bonnes and Secchiaroli 1995) handles relatively little about retail stores. More specifically, environmental psychology concepts have hardly been applied to retailing studies.

Some of the research findings done by environmental psychologists might be applicable to the retailing field. There are some topics studied in an environmental psychology context such as window (Boubekri, Hulliv, and Boyer 1991; Butler and Biner 1989), interior design (Wineman 1982). These could be applicable to the study of store design.

In order to point out the necessity for more specific studies, previous research in relation to the relationships between store design factors and consumer reactions are pooled from environmental psychology, retailing, and marketing areas. Several studies done from an 
environmental psychology perspective dealt with store environments somewhat broadly (e.g. Kotler 1973, Markin, Lillis, and Narayana 1976; Baker, Levy, and Grewal 1992; Baker, Grewal, and Parasuraman 1994).

Markin, Lillis, and Narayana (1976) presented four conceptual propositions arguing that space affects consumer reactions. Harrell, Hutt, and Anderson (1980) have done a study about consumer crowding by using path analysis. In light of the fact that environmental psychology has a relatively long history, their study is one of the first marketing studies in applying environmental psychology concepts. Using the three dimensional approach typified by pleasure, arousal, and dominance, Donovan and Rossiter (1982) found that pleasure and arousal dimensions could affect consumer reactions in their shopping behaviors. Bellizzi, Crowley, and Hasty (1983) found that color of the store interior design affected consumers' physical attraction to the store. Based on a series of focus group interviews, Eroglu and Harrell (1986) described the antecedents and consequences of retail crowding in a conceptual framework.

Baker, Berry, and Parasuraman (1988) have found the effects of in-store environmental variables (e.g. ambient conditions, aesthetics variables, functional design factors, social conditions) on customers and employees of a large bank chain. Baker, Levy, and Grewal (1992) did an experimental study about the effects of in-store environmental variables such as ambient factors (music and lighting) and social factors (store employee's interaction with customers) on consumer reactions measured by pleasure, arousal, and willingness to buy. Without dealing with various design factors, they found that ambient and social variables interacted together and that consumers' pleasure and arousal created by ambient and social factors had positive relationships with consumers' willingness to buy. But, it was also found that ambient and social factors partially affected consumers' pleasure and/or arousal. Baker, Grewal, and Parasuraman (1994) showed three types of store environmental aspects; ambient, design, and social. They found that both ambient and social factors affected consumers' inferences about the quality of stores, but design factor were found not to affect.

\section{Design Factors}

Baker and others (Baker, Berry, and Parasuraman 1988, Baker, Levy, and Grewal 1992, Baker, Grewal, and Parasuraman 1994) have borrowed several concepts from an environmental psychology area and implanted them into a retailing area. Three aspects of store environment were mentioned and partially studied by them such as background music, layout design, and social aspects of store environment (e.g. salespeople greeting consumers). 
Even though the Baker group made a significant contribution to deepen this research area, their studies covered only the broad aspects of store environments. More research is necessary to focus on specific aspects (i.e., ambient, design, social) of store environments. It will definitely deepen the scope of the current research and ripen the content of the current research in the retailing area.

In order to follow this stream, this study chose design factors from the three factors mentioned above. Major reasons are as follows: design factor is more visible than ambient factor like background music. Furthermore, design factor is more controllable than social factor like employees' interactions with consumers in a store.

In an environmental psychology area, several studies were reported about various design factors. Wineman (1982) suggested there were two different viewpoints about open office planning. One is that open office planning can facilitate communication and social interaction. The other is that open office planning can not make environment privately and create mainly non-work-related communications. It appears that window preferences vary across different places. Butler and Biner (1989) tested the concept of window preference across 14 different spaces. They warned any tendency for generalization of the finding to a particular setting. In this sense, in the context of store it may be meaningful to empirically test whether consumers prefer larger and more windows to smaller and few windows. Biner, Butler, and Winsted III (1991) found that inside windows were wanted by people in large buildings.

Boubekri, Hulliv, and Boyer (1991) did an experimental study to find out the relationships between window size and occupant emotional response and satisfaction in an office setting. While different window sizes being controlled, the results didn't find out any significant relationships between window size and emotional state measured by pleasure and arousal and between window size and the degree of satisfaction. This study was done in the context of employees where occupants stay there from morning to night. It seems that there is little research about the relationships between consumer perceptions of window and consumer reactions measured by other constructs (for instance, consumer mood and store image). Butler and Steuerwald (1991), using pre-developed models, found that there seemed to be some differences between natural environment and artificial environment in relation to the view for watching. In relation to in-store display, people may like natural things more than man-made things. For instance, Ittelson (1978) expressed his opinion that people might react better to natural things than to artificial things by arguing that they seek natural things like grass and trees, while they are in urban parks.

In this study, some of environmental psychology concepts which have been developed so 
far are borrowed to explore the relationships between four design factors and two consumer reactions. This study includes four important design factors such as space for moving, viewpoint for watching, in-store display, and window. Four types of design factors are used as predictor variables, whereas two variables of consumer reactions such as consumer mood and store image are used as criterion variables.

\section{Consumer Reactions}

Two variables measured in this study are consumer mood and store image in a retailing context. It is described that consumer mood is an important concept in affecting consumer behavior (e.g. Gardner 1985) and store image has been studied in the context of retailing (Mazursky and Jacoby 1986; Zimmer and Golden 1988).

Most store image studies, such as those done by Mazursky and Jacoby (1986) and done by Zimmer and Golden (1988), have focused largely on products, prices and services, though the relationships of these three factors to the store itself are relatively weak and indirect. Design factors, on the other hand, are much more directly related. Once formed, store image is not easily changed; this also applies to design factors. Store image is construed as a hypothetical construct not easily observed by consumers, and one which can be affected by both product-related factors (products themselves, prices, and possibly others) and storerelated factors (various aspects of design).

In a study of store image, design factors have a special meaning and are among the most important factors affecting consumers. They include physically-oriented variables such as space for viewing and space for gathering, patterns of product arrangement, in-store display and types, sizes and arrangement of windows. In spite of this, most store image studies have, as mentioned earlier, focused on product-related factors. One study (Baker, Grewal and Parasuraman 1994), carried out from an environmental psychology perspective, dealt broadly with how general store environment affects the formation of either a 'prestige' or a 'discount' image, but did not mention the effect on store image of specific design factors. There has been little empirical research on how store-related factors affect store image, and the present study tried to investigate this relationship.

As compared to the veracity of the number of studies about store image, there are few studies reported about consumer mood. Dawson et al. (1990) studied the relationship between music and consumer mood, but this study didn't investigate the relationship between store design factors and consumer mood. A rationale for the inclusion of consumer mood in this study is that consumer mood seems to be short-term oriented, whereas store image appears 
to be long-term oriented.

The main premise of this study is that the relationships between a set of design factors and another set of consumer reactions could be affected by the types of shoppers. In other words, shopping types could direct the feeling, thinking, behaving of the consumers in a retail setting.

\section{Types of Shoppers}

In addition to the concepts of various designs, one of the important concepts in relation to consumers' shopping behavior is the difference between window shopping and actual shopping. To explore the possible differences between window shopping and actual shopping, literature review and a series of interviews were conducted in this study. First, the results of various literature review are described as follows; several kinds of shopping typologies were reported. Moschis (1976) described six types of shopping behaviors such as special shopping, brand-loyal shopping, store-loyal shopping, problem-solving shopping, psychosocializing shopping, and name-conscious shopping. Westbrook and Black (1985) described seven different shopping types.

But, among these, one of the clear distinctions would be the classification of Bellenger, Robertson, and Greenberg (1977) as two different types of shoppers : recreational and economic shoppers. Recreational shoppers are interested in more services and store environments than the products themselves. On the other hand, economic shoppers are mainly concerned with economic incentives approaching the store with low cost and buying good products. These two shopper types were found to be related to shopper characteristics. A key difference between them is that recreational shoppers treat shopping as a leisure, whereas economic shoppers hardly consider it a leisure.

In the study done by Bellenger and Korgaonkar (1980), recreational shoppers were defined as "those who enjoy shopping as a leisure-time activity" (p.78). Eroglu and Machleit (1990) described non-task-oriented shopping and task-oriented shopping. Non-task-oriented buying is not directly related to buying, whereas task-oriented buying is directly related to buying. These two studies expanded the concept of recreational shopping. In this study, based on the literature review, the dichotomization of window shopping and actual shopping was suggested.

Types of shopping activities seem to be related to store-related variables such as store image. Bellenger and Korgaonkar (1980), conducting a study about recreational shopping, stated that experience obtained from a recreational shopping activity was used to form store 

image and this might affect the behavior of the person in relation to the store. Furthermore, it was found that there was a relationship between shopping orientations of buyers and their communication behavior (Moschis 1976).

It appears that shopping motives mentioned in this study may moderate the relationship between design factors and consumer reactions. Dawson, Bloch, and Ridgway (1990) found in their study that different consumer shopping motives measured by product-buying motive and experiential motive might affect consumer reactions measured by pleasure and arousal. More specifically, they found that product motive was more related to pleasure than arousal and the situation was different in the case of experiential motive. Their research suggests that shopping type could play a moderating role in the relationship between design factors and consumer reactions.

\section{Research Framework}

This study focuses on the relationships between four design factors and two consumer reactions. It is proposed that these relationships would be affected by the types of shopping behaviors. The following figure 1 describes the basic research framework of this study.

Figure 1 : Proposed Research Framework

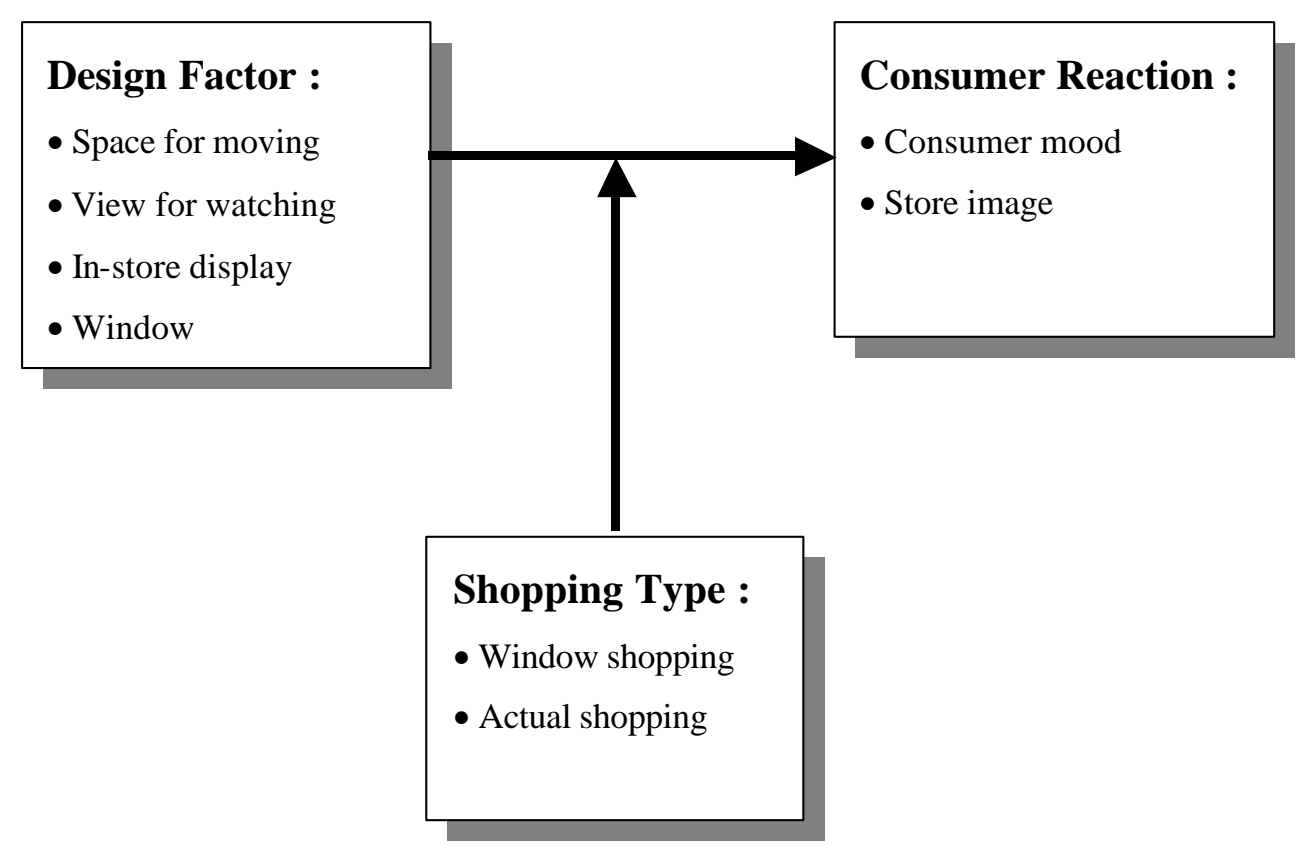




\section{EMPIRICAL INVESTIGATION}

\section{Background of the Empirical Research}

In order to achieve the goal of this research, experimental design was chosen. Pictures of a real store were used as stimuli. The use of pictures has an ecological validity (Bateson and Hui 1992). Pictures have been widely used in the area of environmental psychology (Campbell 1979) and retailing (Eroglu and Machleit 1990). Pictures can be utilized to simulate the actual environments (Hendrick, Martyniuk, Spencer, and Flynn 1977).

A professional photographer was requested to take pictures of interior environments of a big department store located in Seoul, Korea. 32 photos (four pictures for each of four design variables of two levels) were taken for the experiment and these pictures were enlarged to the appropriately large sizes of themselves respectively.

\section{Research Design}

Four variables (four types of design factors) with two different levels respectively were used for the empirical experiment so that eight cells were necessary for the experiment. In order to perform analysis of variance (ANOVA), each cell was comprised of at least 30 respondents. If any subject was found to be participated in the similar experiment before, he/she was asked not to join in the experiment. In total, 555 subjects answered the questionnaire asked.

\section{Experimental Procedures}

The subjects were shown the pictures at eight different groups and asked to answer the questionnaire for measuring the constructs of consumer mood and store image. The measure for consumer mood was originally developed by Peterson and Sauber (1983) and consists of four items measured by a five-point Likert scale. The measure for store image was originally developed by Baker, Grewal, and Parasuraman (1994) and consists of four items measured by a seven-point Likert scale. In order to maintain the comparability between them, scores of store image were converted into a five-point scale.

\section{Results}

In order to test the reliabilities of the measurement scales (consumer mood and store image), Cronbach's Alphas for each design factors were calculated. Seven of the calculated Cronbach's Alphas reported in Table 1 are close to or higher than 0.80 . The results are shown in Table 1. 
한 국 마 케 팅 저 널 제 1 권 제 2 호

Table 1 : Reliabilities(alpha) of Measured Scales of Consumer Mood and Store Image

\begin{tabular}{|l|c|c|}
\hline Tvnes of Variables & Consumer Mood & Store Image \\
\hline Space for Moving & 0.87 & 0.92 \\
\hline Viewpoint for Watching & 0.83 & 0.87 \\
\hline In-store Displav & 0.80 & 0.79 \\
\hline Window for Outside & 0.81 & 0.86 \\
\hline
\end{tabular}

A series of ANOVA was done on the two combinations of variables. One set of variables was about whether the consumer did actual shopping or window shopping. Another set of variable was about the types of four different design factors. For instance, space for moving was either open or closed, viewpoint for watching either unfocused or focused, in-store display either natural or artificial, and window either big or small. Two sets of variables were differently combined and used as independent variables, whereas consumer reactions such as consumer mood and store image were used as dependent variables. Results of the analysis are reported in Table 2 and Figure 2.

Table 2 : Effects of Design Factors and Shopping Types on Consumer Mood and Store Image - All the scales are based on 5-point Likert scales.

\begin{tabular}{|c|l|l|l|}
\hline Types of Variables & Types of Combinations & \multicolumn{1}{|c|}{$\begin{array}{c}\text { Consumer } \\
\text { Mood }\end{array}$} & Store Image \\
\hline Space for Moving & Actual x Open & $2.98(* *)$ & $2.70(* *)$ \\
& Actual x Closed & 2.03 & 1.88 \\
& Window x Open & 3.96 & 3.90 \\
& Window x Closed & 1.99 & 1.37 \\
\hline Viewpoint for & Actual x Focused & $2.72(* *)$ & $2.47(* *)$ \\
Watching & Actual x Unfocused & 2.16 & 1.98 \\
& Window x Focused & 3.27 & 3.27 \\
& Window x Unfocused & 2.33 & 2.13 \\
\hline Instore Display & Actual x Natural & 3.40 & 3.06 \\
& Actual x Artificial & 3.28 & 3.06 \\
& Window x Natural & 3.16 & 3.02 \\
& Window x Artificial & 3.24 & 3.23 \\
\hline Window & Actual x Big & $3.25(* *)$ & $2.92(* *)$ \\
& Actual x Small & 2.81 & 2.61 \\
& Window x Big & 3.04 & 2.93 \\
& Window x Small & 2.39 & 2.01 \\
\hline
\end{tabular}

(*) $\mathrm{p}<0.05$.

$(* *) \mathrm{p}<0.01$. 
Figure 2 : Graphical Representation of the Experiment Results:

The Interaction Effects between Design Factors and Shopping Types

1) Consumer Mood

$$
\text { Space }
$$

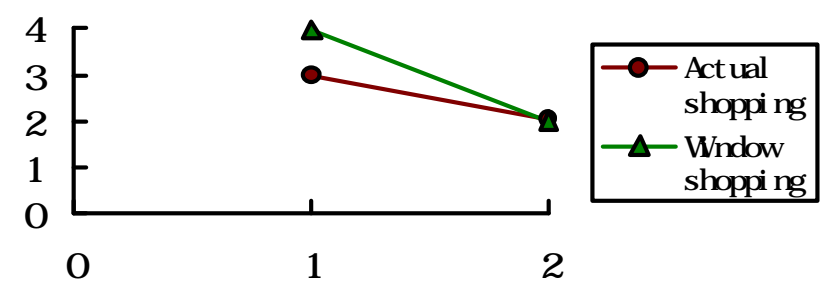

Open $\quad$ Closed

Vi ew for wat ching

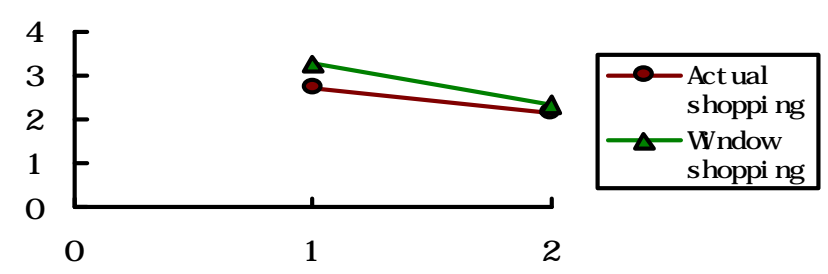

Focused Unfocused

$$
\text { Di spl ay }
$$

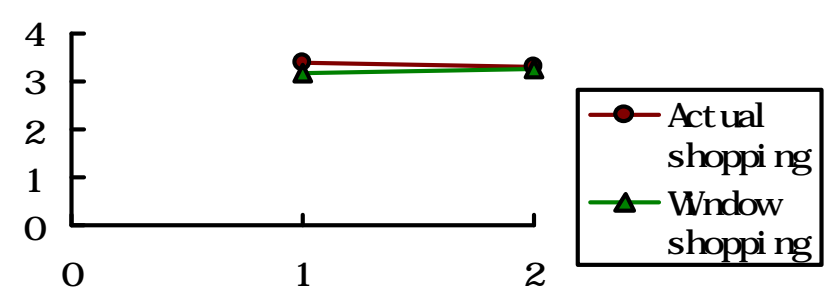

Natural Artificial

\section{W ndow}

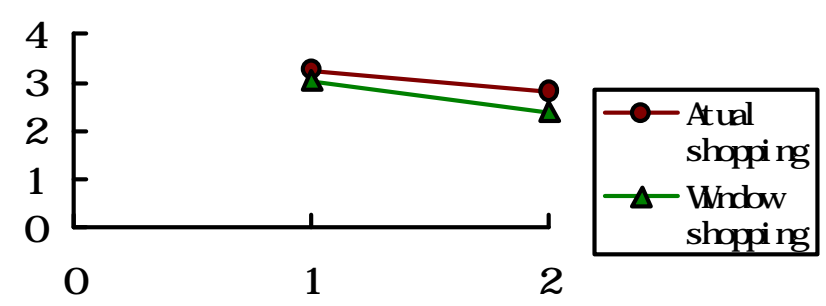

Big Small 
한 국 마 케 팅 저 널 제 1 권 제 2 호 
2) Store Image

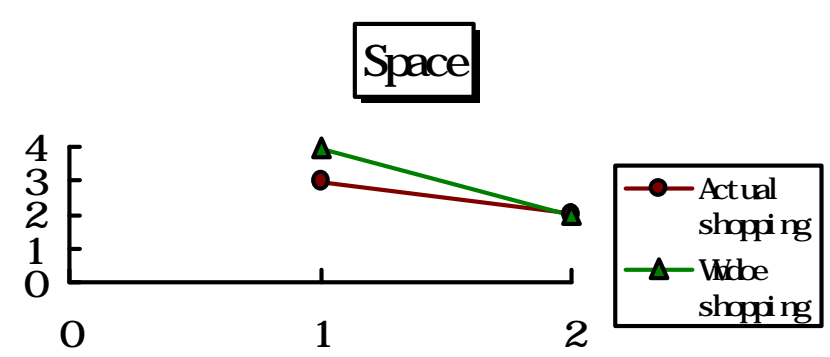

Open Closed

Vi ew for watchi ng

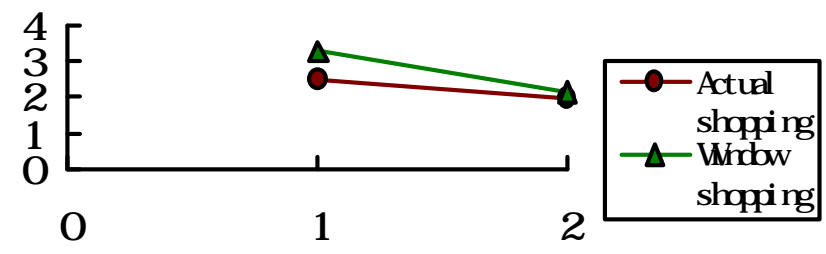

Focused Unfocused
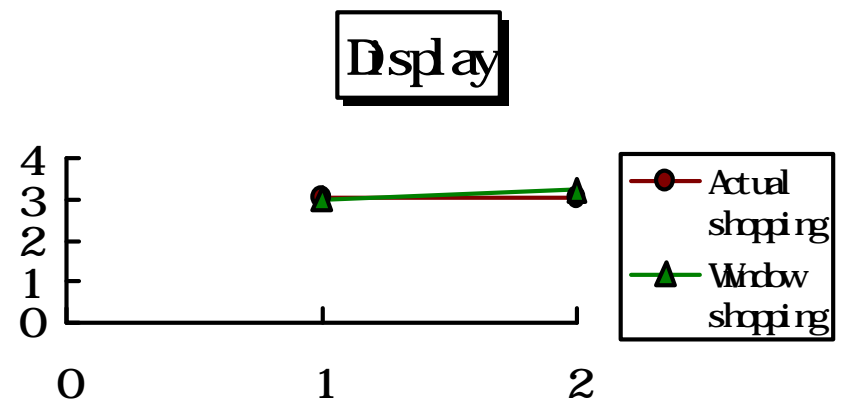

Natural Artificial

\section{Window}

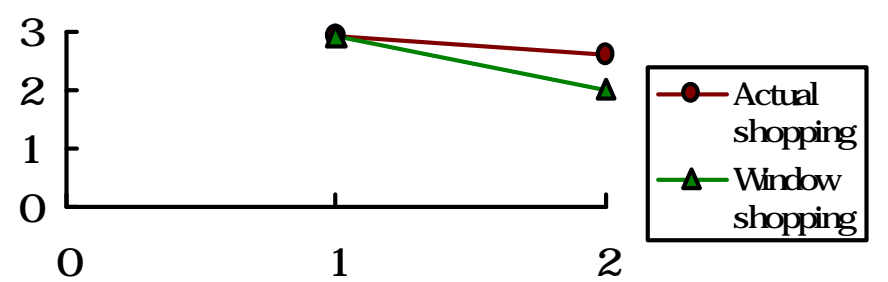

Big Small 


\section{DISCUSSION AND CONCLUSION}

In this study, we tried to investigate how store design creates different consumer reactions measured by consumer mood and store image depending on the types of consumer shopping (i.e. actual shopping vs. window shopping). A series of experiments were done to identify the possible relationships between combinations of variables (two shopping types and four design factors) and consumer reactions (consumer mood and store image) by using the pictures of an actual store. This experimental design could enhance the acceptability of the findings, upon which interpretation may reliably be based.

From the perspectives of managerial implications, the results of this study has some important meanings and interpretations. First, this empirical investigation has identified some differences that consumers react differently according to the combinations of shopping types and design factors, resulting in different consumer mood and store image perceptions. Design factors such as space for moving, viewpoint for watching, and window size can create different perceptions of consumer mood and store image. Good consumer mood and store image could be formed by open space for moving, focused viewpoint for watching, and big window. On the contrary, negative consumer reactions might be acquired by closed space, unfocused viewpoint, and small window.

The experiment results imply that controlling the levels of design factors would create different consumer reactions. Even though good reactions perceived by consumers would not always lead in the increase of direct sales volume, it would promote the specific characteristics (e.g. better consumer mood, prestigious store image, etc.) of the store, enhance the willingness to visit the store by consumers, and increase the duration of staying at the store, while visiting.

Interestingly enough, it was found that consumers create almost same reactions in terms of consumer mood and store image. In other retailing studies, consumer mood was relatively little used (e.g. Gardner 1985), whereas store image has been studied a lot (e.g. Marks 1976; Mazursky and Jacoby 1986; Zimmer and Golden 1988). Nevertheless, there was little difference between consumer mood and store image. Consumer mood may affect the shopping and purchasing behaviors of consumers in a retailing context. It might be good to place more emphasis on consumer mood as well as store image in the future retailing studies. 
Second, it was found that two shopping patterns (actual shopping vs. window shopping) might create different consumer reactions in this study. This typology may be compared to the shopping motives found by Dawson, Bloch, and Ridgway (1990). They mentioned the two motives for visiting stores; product- and experiential-related. Product-related motive is compared to actual shopping type used in this study, since the primary concern of consumers is buying goods at low prices. On the other hand, experiential-related motive is connected to window shopping type. This is because consumers' major concern is on having interesting experiences and/or on looking around.

Furthermore, many department stores are actively engaging in direct selling through catalogues mailed to the customers. For these customers, focusing on actual shopping behavior would be more suitable. For instance, it was found that, among the two types of shopping motives such as economic motive and recreational motive, there seems to be a relationship between catalog shoppers and economic shopping motive (Korgaonkar 1981). These catalog showroom shoppers are largely concerned with prices of products.

Third, research findings could be useful in that a couple of retail strategies could be used. According to the interpretation of the above results, the following concepts may be suggested; discount stores could focus on "actual shoppers," whereas department stores "window shoppers." Actual shoppers should be the major target under bargain sales, whereas window shoppers under normal selling seasons. Furthermore, actual shoppers could be the good target for food selling, whereas window shoppers for fashion selling.

Bellenger and Korgaonkar (1980) found that recreational shoppers in their research consisted of 69 percent of the respondents and that store environmental aspects and merchandising activities were useful tools to appeal to recreational shoppers who considered shopping as a leisure activity. The results of this study strengthen their findings.

Fourth, the overall finding indicates some meaning in relation with store construction. According to Bellenger, Robertson, and Greenberg(1977), smaller shopping centers where supermarkets and drug stores are located may appeal to economic shoppers and larger shopping centers where big department stores are situated could appeal to recreational shoppers. From the findings and the discussion above, it may be useful to consider that small stores like mom and pop stores, small supermarkets, old traditional markets would focus on 
actual shoppers, whereas large stores like modern-style department stores and specialty stores would focus on window shoppers.

Two future research directions may be suggested here. First, in future studies, it would be more meaningful to compare female consumers and male consumers in relation to in-store design factors. There seems to be a gender difference between females and males as to their reactions to the environmental design. Females seem to be more strongly affected than males, because females are more associated with inside arrangements like neatness and decorations (Campbell 1979).

Second, studying how design factors affect consumer mood and store image is important. But, in this study, only the effects of marketer-controllable factors such as design factors were examined. In the context of retailing, non-marketer-controllable factors such as shoppers' appearances, in-store crowdness, and the movement of consumers in a group may affect the perceptions of consumer mood and store image perceptions in a store setting. Gardner (1985) pointed out the importance of comparing the effects of marketer-controlled factors to the effects of non-marketer-controlled factors on consumer mood. This could be a good direction for future studies.

\section{REFERENCES}

Baker, Julie, Leonard L. Berry, and A. Parasuraman (1988), The Marketing Impact of Branch Facility Design, Journal of Retail Banking, Vol. 10, No. 2, Summer, 33-42.

Baker, Julie, Dhruv Grewal, and A. Parasuraman (1994), The Influence of Store Environment on Quality Inferences and Store Image, Journal of the Academy of Marketing Science, Vol. 22, No. 4, 328-339.

Baker, Julie, Michael Levy, and Dhruv Grewal (1992), An Experimental Approach to Making Retail Store Environmental Decisions, Journal of Retailing, Vol. 68, No. 4, Winter, 445-460.

Bateson, John E. G. and Michael K. Hui (1992), The Ecological Validity of Photographic Slides and Videotapes in Simulating the Service Setting, Journal of Consumer Research, Vol. 19, September, 271-281.

Bellenger, Danny N., Dan H. Robertson, and Barnett A. Greenberg (1977), Shopping Center Patronage Motives, Journal of Retailing, Vol. 53, No. 2, Summer, 29-38.

Bellenger, Danny N. and Pradeep K. Korgaonkar (1980), Profiling the Recreational Shopper, 
Journal of Retailing, Vol. 56, No. 3, Fall. 77-92.

한 국 마 케 팅 저 널 제 1 권 제 2 호

Bellizzi, Joseph A., Ayn E. Crowley, and Ronald W. Hasty (1983), The Effects of Color in Store Design, Journal of Retailing, Vol. 59, No. 1, Spring, 21-45.

Biner, Faul M., Darrell L. Butler, and Donald E. Winsted III. (1991), Inside Windows: An Alternative to Conventional Windows in Offices and other Setting, Environment and Behavior, Vol. 23, No. 3, May, 359-382.

Bonnes, Mirilia and Gianfranco Secchiaroli (1995), Environmental Psychology - A Psychosocial Introduction, Sage Publications.

Boubekri, Mohamed, Robert B. Hulliv, and Lester L. Boyer (1991), Impact of Window Size and Sunlight Penetration on Office Workers' Mood and Satisfaction - A Novel Way of Assessing Sunlight, Environment and Behavior, Vol. 23, No. 4, July, 474-493.

Butler, Darrell L. and Paul M. Biner (1989), Effects of Setting on Window Preferences and Factors associated with their Preferences, Environment and Behavior, Vol. 21, No. 1, January, 17-31.

Butler, Darrell L. and Brian L. Steuerwald (1991), Effects of View and Room Size on Window Size Preferences made in Models, Environment and Behavior, Vol. 23, No. 3, May, 334-358.

Campbell, David E. (1979), Interior Office Design and Visitor Response, Journal of Applied Psychology, Vol. 64, No. 6, 648-653.

Dawson, Scott, Peter H. Bloch, and Nancy M. Ridgway (1990), Shopping Motives, Emotional States, and Retail Outcomes, Journal of Retailing, Vol. 66, No. 4, Winter, 408-427.

Donovan, Robert J. and John R. Rossiter (1982), Store Atmosphere: An Environmental Psychology Approach, Journal of Retailing, Vol. 58, No. 1, Spring, 34-57.

Eroglu, Sevgin and Gilbert D. Harrell (1986), Retail Crowding: Theoretical and Strategic Implications, Journal of Retailing, Vol. 62, No. 4, Winter, 346-363.

Eroglu, Sevgin A. and Karen A. Machleit (1990), An Empirical Study of Retail Crowding: Antecedents and Consequences, Journal of Retailing, Vol. 66, No. 2, Summer, 201-221.

Gradner, Meryl Paula (1985), Mood States and Consumer Behavior: A Critical Review, Journal of Consumer Research, Vol. 12, December, 281-300.

Harrell, Gilbert D., Michael D. Hutt, and James C. Anderson (1980), Path Analysis of Buyer Behavior Under Conditions of Crowding, Journal of Marketing Research, February, 45-51.

Hendrick, Clyde, Osyp Martyniuk, Terry J. Spencer, and John E. Flynn (1977), Procedures for Investigating the Effect of Light on Impression - Simulation of a Real Space by Slides, Environment and Behavior, Vol. 9, No. 4, December 491-510.

Ittelson, William H. (1978), Environmental Perception and Urban Experience, Environment and Behavior, Vol. 10, No. 2, June, 193-215.

Korga onkar, Pradeep K. (1981), Shopping Orientations of Catalog Showroom Patrons, Journal of Retailing, Vol. 57. No. 1, Spring, 78-90.

Kotler, Philip (1973), Atmosphere as a Marketing Tool, Journal of Retailing, Vol.49, Winter, 48-61.

Markin, Rom J., Charles M. Lillis, and Chem L. Narayana (1976), Social-Psychological Significance of Store Space, Journal of Retailing, Vol. 52, No. 1, Spring, 43-54.

Marks, Ronald B. (1976), Operationalizing the Concept of Store Image, Journal of Retailing, 
Vol. 52, No. 3, Fall, 37-46.

Mazursky, David and Jacob Jacoby (1986), Exploring the Development of Store Images, Journal of Retailing, Vol. 62, No. 2, Summer, 145-165.

Moschis, George P. (1976), Shopping Orientations and Consumer Uses of Information, Journal of Retailing, Vol. 52, No. 2, Summer, 61-70 \& 93.

Peterson, Robert A. and Matthew Sauber (1983), A Mood Scale for Survey Research, in American Marketing Association Educator Proceedings, Patrick Murphy et al. (eds), Chicago: The American Marketing Association, 409-414.

Westbrook, Robert A. and William C. Black (1985), A Motivation-Based Shopper Typology, Journal of Retailing, Vol. 61, No. 1, Spring, 78-103.

Wineman, Jean D. (1982), Office Design and Evaluation - An Overview, Environment and Behavior, Vol. 14, No. 3, May, 271-298.

Zimmer, Mary R. and Linda L. Golden (1988), Impressions of Retail Stores: A Content Analysis of Consumer Images, Journal of Retailing, Vol. 64, No. 3, Fall, 265-293. 